\title{
WYKORZYSTANIE RZECZYWISTOŚCI ROZSZERZONEJ W ŻYCIU CODZIENNYM
}

\author{
Maciej Laskowski ${ }^{1}$, Damian Rawski ${ }^{2}$, Przemysław Szadura ${ }^{2}$ \\ ${ }^{1}$ Instytut Informatyki, Wydział Elektrotechniki i Informatyki, Politechnika Lubelska, ${ }^{2}$ Koło Naukowe Informatyki PENTAGON, Politechnika Lubelska
}

Streszczenie: $W$ ostatnich latach gwaltowny rozwój telefonii komórkowej powoduje powstawanie nowych interesujacych technologii, takich jak system Layar wykorzystujący rozszerzona rzeczywistość. Jest to platforma wzbogacajaca otaczajacy nas świat o cyfrowe informacje. Poniższy artykuł opisuje wykorzystanie tej technologii w tworzeniu wirtualnego przewodnika po uczelni, wspierajacego bezproblemowe poruszanie się po terenie kampusu. Zawiera on opis problemu, technologie wykorzystywane w tym projekcie oraz zastosowanie go w prawdziwym życiu.

Słowa kluczowe: Layar, Rzeczywistość Rozszerzona, smartfon, wirtualny przewodnik

\section{AUGMENTED REALITY - THE WAY TO USING ADVANCED TECHNOLOGY IN NORMAL LIFE}

\begin{abstract}
The rapid growth of smartphone market share is a key factor for both developing and implementing many solutions dedicated to mobile devices. One of the most promising technologies is Layar - a mobile platform for discovering digital information about the physical world using Augmented Reality (AR). This paper describes the implementation of Layar in creating a virtual guide of university campus in order to help finding particular buildings and other kinds of campus information needed. The issues of creating an information layer containing all the necessary information about the campus buildings are also discussed.
\end{abstract}

Keywords: Layar, Augmented Reality, smartphone, virtual guide

\section{Wstęp}

Ostatnimi czasy możemy zaobserwować ogromny rozwój w dziedzinie telefonii komórkowej, a zwłaszcza w segmencie tzw. smartfonów, czyli telefonów posiadających system operacyjny, ekran dotykowy i/lub klawiaturę QWERTY [4] (rys. 1).

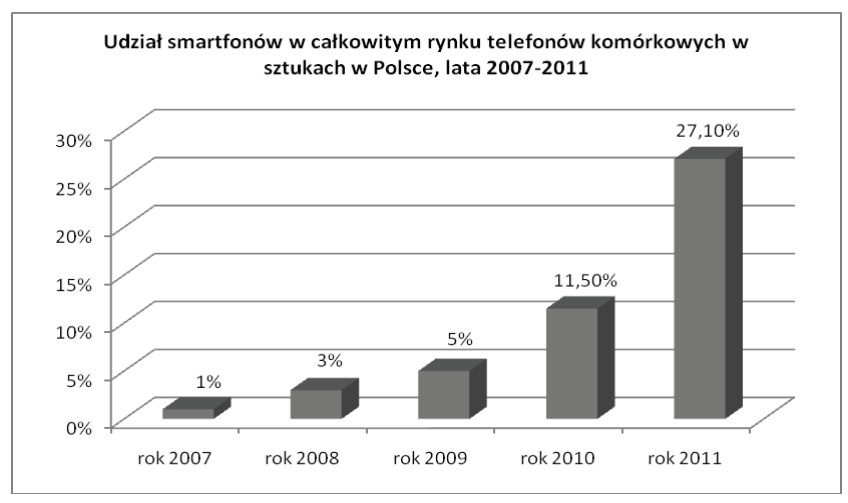

Rys. 1. Udzial smartfonów $w$ calkowitym rynku telefonów komórkowych w sztukach $w$ Polsce w latach 2007-2011 [4]

Warto nadmienić, iż obecnie systemem operacyjnym, który zyskuje największą popularność jest system Android rozwijany przez Google i oparty na jądrze Linuxa. Dodatkowo właściciele smartfonów korzystają z wielu dodatkowych multimedialnych funkcji, które oferuje sprzęt, a mianowicie: GPS, przeglądarka WWW, poczta elektroniczna czy wideokonferencje. Wszystkie te czynniki sprawiają, iż technologia komórkowa rozwija się w szybkim tempie, przez co pojawia się wiele usług i aplikacji dedykowanych na tego typu urządzenia.

W 1994 roku Paul Milgram i Fumio Kishino określili koncepcję schematu ciągłości rzeczywistość - wirtualność (Virtuality Continuum, VC), formułującą definicję rzeczywistości mieszanej (Mixed Reality, MR) oraz przedstawili relacje pomiędzy światem rzeczywistym a wirtualnym [8].

Jeśli za jeden $\mathrm{z}$ końców schematu (rys. 2) ciągłości przyjmiemy środowisko rzeczywiste, a drugi zaś za wirtualne, wtedy rzeczywistość rozszerzona umiejscowiona jest na schemacie tuż przy środowisku rzeczywistym. Im bliżej systemowi do wirtualnej rzeczywistości, tym bardziej zredukowana jest liczba elementów rzeczywistych.

Systemy typu „see-through", gdzie obraz jest najczęściej generowany bezpośrednio na urządzeniu optycznym) znajdują się bliżej świata prawdziwego w porównaniu do systemów używających technik mieszania obrazu wideo (Video-Mixing) [8].
Rzeczywistość może być „rozszerzana” o wirtualne obiekty, analogicznie do tego świat wirtualny może być „rozszerzany” przez rzeczywiste obiekty [8]. Takie Środowisko nazywane jest Rozszerzoną Wirtualnością (Augmented Virtuality, AV) i na schemacie ciągłości rzeczywistość - wirtualność umiejscowiona jest tuż przy środowisku wirtualnej rzeczywistości [8].

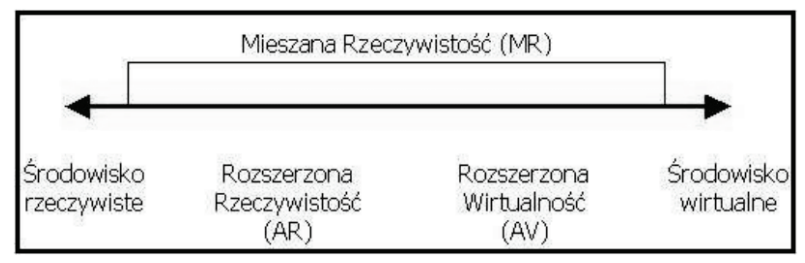

Rys. 2. Schemat ciaglości rzeczywistość-wirtualność [7]

Zgodnie z definicją, System Rzeczywistości Rozszerzonej powinien (za: [1]):

- $\quad$ łączyć w sobie świat wirtualny i rzeczywisty;

- umożliwiać interakcję w czasie rzeczywistym;

- umożliwiać swobodę ruchów w płaszczyźnie trójwymiarowej.

Rzeczywistość rozszerzona nie generuje więc oddzielnego, całkowicie cyfrowego świata, lecz opiera się na realnym, wzbogacając informacje o istniejących miejscach bądź obiektach dzięki nakładaniu na nie wirtualnych elementów zawierających dodatkowe dane, często w postaci multimedialnej [5]. Odbywa się to zazwyczaj przy pomocy odpowiedniej aplikacji, która analizuje i wzbogaca obraz widziany przez wbudowaną w smartfon kamerę.

Sama idea Rozszerzone Rzeczywistości nie jest nowa - prace nad nią rozpoczął w latach 60 -tych XX wieku Ivan Sutherlan ze studentami Uniwersytetu Harvarda i Uniwersytetu Utah. Wraz z rozwojem technologii systemy AR zaczęły wychodzić poza ściany zamkniętych środowisk, w celu pokazania użytkownikowi grafiki 2D lub modelu 3D bezpośrednio w terenie za pomocą mobilnych, osobistych urządzeń wyświetlających informacje wirtualne nakładane na obraz rzeczywistego świata [8].

Rozszerzoną Rzeczywistość charakteryzuje duży potencjał rozwoju, może ona być zastosowana do m.in. stworzenia kompleksowego przewodnika (np. po mieście), gdyż pozwala na wyświetlanie mapy na ekranie telefonu komórkowego, natychmiastowo lokalizuje użytkownika na tle pobliskich atrakcji turystycznych (za pomocą GPS), czy też pełni funkcję nawigatora - kieruje użytkownika do obranego celu, kolejnego obiektu..

Jak się przewiduje [5], w najbliższym czasie powstanie wiele interesujących rozwiązań, m.in. umożliwiających użytkownikowi wizualizację projektów architektonicznych w odniesieniu do konkretnego terenu lub produktów, które klient będzie mógł 
obejrzeć przed zakupem. (np. umożliwienie przymierzenia projektowanych ubrań bez konieczności ich fizycznego tworzenia).

Jak można zauważyć, możliwości zastosowania Rozszerzonej Rzeczywistości są olbrzymie.

Warto więc zastanowić się nad możliwością zastosowania rozwiązań $\mathrm{z}$ tej dziedziny $\mathrm{w}$ życiu zwykłego użytkownika już w chwili obecnej.

\section{Problem lokalizacji miejsc na kampusie}

Jednym z najpopularniejszych zastosowań systemów Rozszerzonej Rzeczywistości są lokalizatory. Najpopularniejsze implementacje są tworzone zazwyczaj w celach reklamowopromocyjnych [6]. Warto jednak zastanowić się nad zastosowaniami o nieco większym znaczeniu społecznym. Przykładem tego rodzaju wykorzystania Rzeczywistości Rozszerzonej może być wspomaganie poruszania się po kampusach uczelni.

Jednym z największych problemów z jakimi muszą borykać się studenci, szczególnie pierwszych lat studiów (zarówno I, jak i II stopnia) jest kwestia poruszania się po terenie uczelni oraz odnalezienie właściwego budynku i sali, gdzie odbywają się zajęcia. Problem ten jest szczególnie widoczny w przypadku kampusów o strukturze rozproszonej.

Dobrą ilustracją omawianego zagadnienia jest przykład Lublina - największego ośrodka akademickiego w Polsce Wschodniej [11].

$\mathrm{Na}$ terenie miasta działa w sumie dwanaście uczelni, w tym pięć państwowych, przy czym kampusy większości $\mathrm{z}$ nich są rozrzucone po terenie całego miasta. Dobrą ilustracją problemu mogą być tutaj Uniwersytet Przyrodniczy i Katolicki Uniwersytet Lubelski - studenci obydwu tych uczelni mają często zajęcia w obiektach umieszczonych na przeciwległych końcach Lublina Oznacza to, że odnalezienie właściwego budynku i terminowe dotarcie na zajęcia może być dla studentów swoistym wyzwaniem. Poruszanie się po nawet relatywnie zwartym terenie uczelni (np. Politechniki Lubelskiej) może stanowić problem spowodowany m.in. przez trwające budowy, zmieniające nie tylko wygląd kampusu, ale i sposób poruszania się po nim.

Standardowym rozwiązaniem jest tradycyjna papierowa mapka lub inny dokument prezentujące plan kampusu oraz zawierające podstawowe informacje organizacyjne, jak chociażby rozkład zajęć. Często jednak charakteryzują się ona sporym stopniem niedokładności czy wręcz nieaktualności, gdyż np. nie uwzględniają aktualnych zmian w topografii kampusu (wynikających chociażby z trwających prac budowlanych). Dodatkowo wszystkie takie informacje charakteryzuje brak zwartości, gdyż zazwyczaj są umieszczane na oddzielnych dokumentach. Powoduje to konieczność posługiwania się np. kilkoma różnymi wydrukami jednocześnie, co oczywiście może powodować dyskomfort użytkownika i zwiększać stopień jego dezorientacji.

Pytanie, jakie się nasuwa podczas analizy opisywanego problemu brzmi: w jaki sposób można wykorzystać systemy rozszerzonej rzeczywistości do ułatwienia życia użytkownikowi?

Odpowiedzią może być system Layar.

\section{Layar}

Layar to pierwsza na świecie mobilna platforma współpracująca z otaczającą użytkownika rzeczywistością. System działa na urządzeniach mobilnych wyposażonych w GPS, kamerę, kompas, akcelerometr oraz stałe połączenie internetowe minimum $\mathrm{w}$ technologii 2G. Wszystkie aktualnie dostępne na rynku smartfony (bez względu na wykorzystywany system operacyjny Android, Symbian, BadaOS, IOS, RIM) spełniają te wymagania. Warto również zauważyć, że Layar jest darmowy dla każdej platformy mobilnej.

System, stworzony przez firmę SPRXMobile, był początkowo dostępny tylko w Holandii - dopiero w sierpniu 2009 API systemu doczekało się premiery światowej. Rozgłos i spory sukces zawdzięcza sklepowi z aplikacjami - Android Market, który jest dostępny pod adresem http://market.android.com.

Później program zdobył nowe możliwości, w tym prezentowanie obiektów opartych na technologii OpenGL, tworzenia płatnych warstw czy możliwości rozpoznawania obrazów po stronie klienta. Obecnie wprowadzona została nowa wersja API - 6.2, która umożliwia także prezentowanie warstwy filmowej [2].

Sama aplikacja jest bezpłatna, jednak można uaktualniać ją o płatne warstwy oferujące ogromną ilość informacji, co pozwala na wykorzystanie w pełni oferowanych przez system możliwości.

Warto zauważyć, że pomimo istnienia kilku systemów obsługujących Rozszerzoną Rzeczywistość, to właśnie Layar cieszy się największą popularnością (rys. 3).

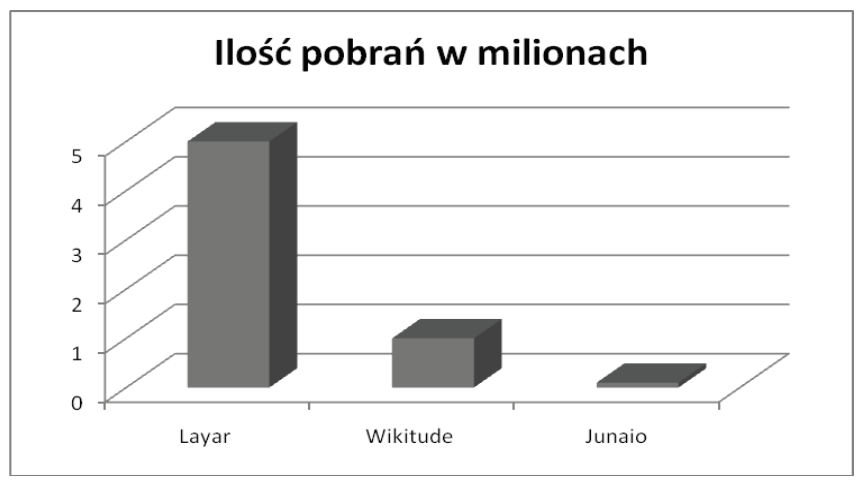

Rys. 3. Ilość pobrań ( $w$ milionach) przegladarek wirtualnej rzeczywistości (źródto: opracowanie wtasne na podstawie danych z Android Market z lipca 2011)

\section{Layar - jak to dziala?}

Cała idea Layara opiera się na tworzeniu tzw. warstw (ang. layer). Jest to cyfrowa nakładka zawierająca wszystkie interesujące nas informacje na dany temat. Całość działa w ten sposób iż, na obraz z kamery smartfonu nakładane są - w oparciu o położenie geograficzne - cyfrowe informacje odnośnie obiektu znajdującego się w obiektywie kamery.

W systemie Layar warstwy tworzone są w oparciu o technologie sieciowe: dozwolone jest użycie m.in. PHP, MySQL oraz Java. Jedynym kryterium walidacji warstwy jest jej zgodność $\mathrm{z}$ formatem JSON.

JSON, czyli JavaScript Object Notation to lekki format wymiany danych komputerowych [3]. JSON jest formatem tekstowym, będącym podzbiorem języka JavaScript, jednak pomimo tego faktu jest formatem niezależnym od konkretnego języka, dzięki czemu wiele języków programowania korzysta $\mathrm{z}$ tego formatu danych przez dodatkowe pakiety czy biblioteki [3].

Oczywiście przy tworzeniu warstwy do dyspozycji jest również wiele płatnych narzędzi, dzięki którym nawet osoby nie mające pojęcia o programowaniu, mogą tworzyć własne warstwy.

Swoją przygodę $\mathrm{z}$ Layarem należy rozpocząć od zarejestrowania się na stronie www.layar.com, następnie należy utworzyć konto developerskie na stronie www.layar.com/development.

Kolejnym krokiem jest stworzenie definicji warstwy (www.layar.com/publishing). Należy w niej podać jedynie tytuł $i$ opis warstwy oraz adres do naszej strony internetowej. Jest to strona obsługująca połączenie naszej warstwy $\mathrm{z}$ bazą danych zawierającą wszystkie informacje odnośnie obiektów. $\mathrm{Na}$ stronie Layara istnieje samouczek, który przeprowadzi nas przez wszystkie kroki tworzenia warstwy, a także jest zaprezentowany przykładowy kod strony obsługujący wspomniane wyżej połączenie $\mathrm{z}$ bazą danych.

W tym momencie przychodzi pora na obsłużenie połączenia naszej bazy danych $\mathrm{z}$ warstwą prezentacyjną. Jak zostało wspomniane wyżej, na stronie znajduje się przykładowy kod takiej obsługi. Pierwszą i najważniejszą sprawą, przy tworzeniu Layara jest to by posiadać własny serwer danych, na których 
przechowywane będą wszystkie potrzebne informacje. Teraz pozostaje tylko odpowiednie przeformatowanie przykładowego kodu obsługi bazy, tak by działał z naszym serwerem. Tych modyfikacji należy dokonać w pliku config.inc, w którym znajdują się definicje zmiennych do połączenia $\mathrm{z}$ bazą danych.

Po ukończeniu opisanych powyżej kroków nowopowstała warstwa $z$ odpowiednimi parametrami jest już niemal gotowa.

Warto teraz przetestować połączenie bazy danych z warstwą. Logujemy się zatem na stronie www.layar.com na nasze konto deweloperskie, przechodzimy do zakładki „my layers” i klikamy na przycisk Test. Przechodzimy teraz na stronę testową, w której widzimy mapę pewnego obszaru a na niej pewien zasięg wyróżniony innym kolorem. Jest to testowy zasięg potencjonalnego użytkownika.

Ustawiamy ten zasięg na okolice nas interesujące i sprawdzamy działanie warstwy. Jeśli zostają wczytane wszystkie punkty to warstwa działa poprawnie, jeśli nie, ewentualne błędy można sprawdzić w konsoli poniżej.

Pozostaje teraz wyruszenie sprzed ekranu komputera, aby dokonać odpowiednich pomiarów współrzędnych geograficznych (lub sprawdzenie ich np. w Google Maps) i wpisać je do bazy danych.

Gdy wszystko już działa sprawnie, w zakładce „my layers” klikamy na przycisk „Request approval”, co powoduje oficjalne opublikowanie naszej warstwy w serwisie Layar.

\section{Wybrane zastosowania technologii Layar w Polsce}

Jak zostało już wspomniane wcześniej, jednym z najpopularniejszych zastosowań technologii Layar jest tworzenie różnego rodzaju wirtualnych przewodników.

Pierwszym miastem w Polsce, które dysponowało oficjalnym przewodnikiem wykonanym w technologii Layar były Katowice. Na początku 2010 roku udostępniono dwujęzykową (po polsku $\mathrm{i}$ angielsku) mapę Katowic składającą się $\mathrm{z} \quad 4$ kategorii wyświetlanych w zależności od wyboru użytkownika: kultura i rozrywka, służba publiczna i transport, hotele oraz wydarzenia [9]. Mapa zawiera 50 POI (Points of interest) - głównie budynki użyteczności publicznej - z których każdy posiada opis miejsca oraz formularz kontaktowy, dzięki któremu bezpośrednio $\mathrm{z}$ aplikacji można się z tym miejscem skontaktować. Ciekawym rozwiązaniem jest również warstwa Wydarzenia, która dzięki ciągłym aktualizacjom pełni rolę repertuaru.

Kolejnym miastem, które stosuje w swoich działaniach Rzeczywistość Rozszerzoną jest Lublin. Ośrodek „Brama Grodzka - Teatr NN" - instytucja kultury działająca w Lublinie na rzecz ochrony dziedzictwa kulturowego i edukacji po raz pierwszy zastosował technologie AR w 2011 roku podczas wystawy prac niemieckiej artystki Urlike Grossarth w Lublinie. Było to jednak działanie czasowe, które zakończyło się wraz z wystawą [10].

Kolejnym działaniem był projekt „Przewodniki. Lublin 2.0”. Warstwa opracowana $\mathrm{w}$ ramach tego projektu warstwa zawiera 11 szlaków (za: [10]):

- Zabytki Lublina,

- Żydowski Lublin (w dwujęzycznej: polskoangielskiej wersji),

- $\quad$ Lublin Od Unii Lubelskiej do Unii Europejskiej,

- Lublin 1918 roku,

- Lublin Hartwigów,

- Lublin Stefana Kiełszni,

- Architektura poprzemysłowa

- Poemat o mieście Lublinie,

- Wiersze o Lublinie, Modele 3D,

- Historie Mówione o Lublinie.

Szlaki te zawierają w sumie 145 punktów (Zabytki Lublina 28 punktów, Żydowski Lublin - 18 punktów, Lublin Od Unii Lubelskiej do Unii Europejskiej - 11, Lublin 1918 roku - 7, Lublin Hartwigów - 10, Architektura Poprzemysłowa - 39,
Poemat o mieście Lublinie - 14, Wiersze o Lublinie- 10, Modele $3 \mathrm{D}-8)[10]$.

Szlaki można ze sobą łączyć - poszczególne elementy tworzą zintegrowany system, prezentujący w sposób przystępny i atrakcyjny kompleksową wiedzę o historii i dziedzictwie kulturowym miasta [10].

Warto zauważyć, że punkty na szlakach różnią się pod względem zawartości. Szlaki dotyczące dziedzictwa kulturowego - Zabytki Lublina, Żydowski Lublin, Architektura poprzemysłowa oraz historii Lublina: Lublin Od Unii Lubelskiej do Unii Europejskiej czy Lublin 1918 roku opierają się na krótkich tekstach opisujących miejsca lub wydarzenia. Każdy z nich jest uzupełniony ilustracją i linkiem przekierowującym do artykułu szerzej omawiającego zagadnienie [10]

Szlaki: Poemat o mieście Lublinie i Wiersze o Lublinie dostarczają materiał audio: w przypadku Poematu o Lublinie utwór Józefa Czechowicza czytany przez poetów, m.in. przez Czesława Miłosza i Wisławę Szymborską, natomiast na szlaku Wierszy o Lublinie wybrane wiersze dotyczące miasta interpretuje jedna osoba - aktor Teatru NN - Witold Dąbrowski. Materiał audio zawiera także szlak Historii Mówionych. Podczas spaceru tym szlakiem można odsłuchać krótkie fragmenty wspomnień mieszkańców Lublina zebranych w ramach projektu Historia Mówiona [10].

Jeszcze inny rodzaj materiału zawiera szlak Lublin Stefana Kiełszni. Stefan Kiełsznia był fotografem międzywojennego Lublina [10]. Patrząc na ekran urządzenia następuje nałożenie archiwalnego zdjęcia z 1934 roku na widok współczesny.

Kolejny szlak - Szlak Hartwigów - znanej lubelskiej rodziny zawiera różnorodne materiały, od tekstów, poprzez materiały audio do fotografii [10].

Ostatni ze szlaków przewodnika - Modele 3D, wykorzystuje elementy z projektu „Lublin 2.0. Interaktywna rekonstrukcja dziejów miasta". Na szlaku umieszczono 8 modeli budynków, które już nie istnieją (kościół farny rozebrany w XVIII wieku i Wielka Synagoga zniszczona w 1944 roku) lub w znaczący sposób zmieniły swój wygląd [10].

Warto podkreślić, że $\mathrm{w}$ Lublinie technologia AR została w 2012 roku wykorzystana dwukrotnie podczas wydarzeń kulturalnych - Noc Kultury i Carnaval Sztukmistrzów.

W obu przypadkach dzięki tej technologii stworzono multimedialne mapy punktów, w których odbywały się imprezy kulturalne.

\section{Zastosowanie systemu Layar na przykładzie wirtualnego kampusu}

Celem prac podjętych w ramach Koła Naukowego Informatyki Pentagon jest stworzenie wirtualnego przewodnika po kampusie, którego zadaniem będzie ułatwienie studentom i osobom odwiedzającym uczelnie w bezproblemowym poruszaniu się po terenach uczelni.

Wirtualny kampus będzie oparty o technologię Layar, która wydaje się być dobrym rozwiązaniem opisanych powyżej problemów.

Użytkownik mając do dyspozycji jedynie swój własny telefon może dowiedzieć się w ciągu kilku sekund, gdzie znajduje się konkretny budynek, jak do niego dojść, jego adres, numer telefonu właściwego dziekanatu, strona internetowa wydziału, plany zajęć, rozkłady sal - jednym słowem ma możliwość zdobycia praktycznie wszystkie potrzebne informacji dotyczące uczelni.

\section{Zakończenie}

Rozszerzona rzeczywistość tworzy zupełnie nową jakość w projektowaniu aplikacji użytkowych. Co więcej, dzięki relatywnie prostemu procesowi projektowemu, umożliwia zaangażowanie w rozwój elementów aplikacji także użytkowników nie dysponujących wiedzą informatyczną. Jest to szczególnie istotne w przypadku systemów takich jak Layar - opierających się w dużej mierze o treści dostarczane właśnie przez użytkowników. 
Projekt wirtualizacji uczelnianego kampusu stanowi dopiero przyczynek do rozwinięcia zagadnienia inteligentnego miasta przyszłości. Jednak dzięki dość szerokiej i dynamicznej grupie odbiorców (głównie młodzi ludzie, otwarci na nowe technologie) stanowi znakomity poligon doświadczalny dla testowania zarówno możliwości, jak i ograniczeń systemu, co pozwoli na udoskonalenie przyszłych implementacji tego projektu.

\section{Literatura}

[1] Azuma R.: A Survey of Augmented Reality, Presence: Teleoperators and Virtual Environments, 1997, s. 355-385.

[2] Cameron C.: Layar 6.1 Update Now in App Stores, http://layar.com/blog/2012/02/14/layar-61-now-in-app-stores/, 2012.

[3] Crockford, D.: JSON: The Fat-Free Alternative to XML http://www.json.org/fatfree.html, 2006.

[4] Hatalska N.: Penetracja smartfonów w Polsce - dane za 2011, http://hatalska.com/2012/02/13/penetracja-smartfonow-w-polsce-dane-za2011/, 2012.

[5] Konecki T.: Rzeczywistość rozszerzona - lepsza wersja świata, http://nt.interia.pl/news/rzeczywistosc-rozszerzona-lepsza-wersjaswiata, 1651714, 2011

[6] Madden L.: Professional Augmented Reality Browsers for Smartphones: Programming for junaio, Layar and Wikitude, Chicester, John Wiley \& Sons 2011.

[7] Milgram P., Kishino F,: A taxonomy of mixed reality visual displays. IEICE Transactions on Information Systems, 1994, E77-D(12)

[8] Pardel P.: Przegląd ważnych zagadnień rozszerzonej rzeczywistości, Studia Informatica, t. 30, nr 1 (82), Politechnika Śląska 2009.

[9] Tomaszewski J.: Mapa Katowic w aplikacji Layar. Jako pierwsza z polskich miast, http://www.mmsilesia.pl/250367/2010/9/9, 2010.

[10] Zetar J.: Przewodniki. Lublin 2.0 - przewodniki po Lublinie z wykorzystaniem poszerzonej rzeczywistości. Studium przypadku, praca seminaryjna napisana pod kierunkiem prof. dr hab. Andrzeja Szromnika w ramach studiów podyplomowych Akademii Dziedzictwa, działającej w ramach Międzynarodowego Centrum Kultury, 2012.

[11] Żyła K.: Broniszewski T., Budzyński A., Usługi lokalizacyjne w inteligentnym mieście na przykładzie mobilnego przewodnika po uczelni, Zeszyty naukowe Uniwersytetu Szczecińskiego. Studia Informatica, No.29 Vol.721, 2012, pp.7-19.
Mgr inż. Maciej Laskowski

e-mail: m.laskowski@pollub.p

Asystent w Instytucie Informatyki Politechniki Lubelskiej. Absolwent studiów magisterskich na kierunku Informatyka (specjalność Inżynieria Oprogramowania) na Wydziale Elektrotechniki i Informatyki Politechniki Lubelskiej (2007). Absolwent studiów podyplomowych Public Relations w Badaniach Naukowych w Wyższej Szkole Ekonomii i Innowacji w Lublinie w 2009 roku. Opiekun Koła Naukowego Informatyki PENTAGON. W swoich badaniach naukowych zajmuje się tematyką osób niepełnosprawnych (szczególnie posiadających różnego rodzaju wady wzroku) w Internecie, a także szeroko pojętą tematykę usability.

\section{Inż. Damian Rawski}

Absolwent studiów inżynierskich na kierunku Informatyka na Wydziale Elektrotechniki i Informatyki Politechniki Lubelskiej.

Członek Koła Naukowego Informatyki PENTAGON. Laureat „konkursu na Projekt” dotyczącego promocji Lubelszczyzny realizowanego przez Biuro Poselskie prof. Leny Kolarskiej - Bobińskiej, Poseł do Parlamentu Europejskiego (temat: wirtualny przewodnik po uczelni)

\section{Inż. Przemysław Szadura}

Absolwent studiów inżunierskich na kierunku informatyki na Wydziale Elektrotechniki i Informatyki Politechniki Lubelskiej.

Członek Koła Naukowego Informatyki PENTAGON Laureat „konkursu na Projekt” dotyczącego promocji Lubelszczyzny realizowanego przez Biuro Poselskie prof. Leny Kolarskiej - Bobińskiej, Poseł do Parlamentu Europejskiego (temat: wirtualny przewodnik po uczelni)
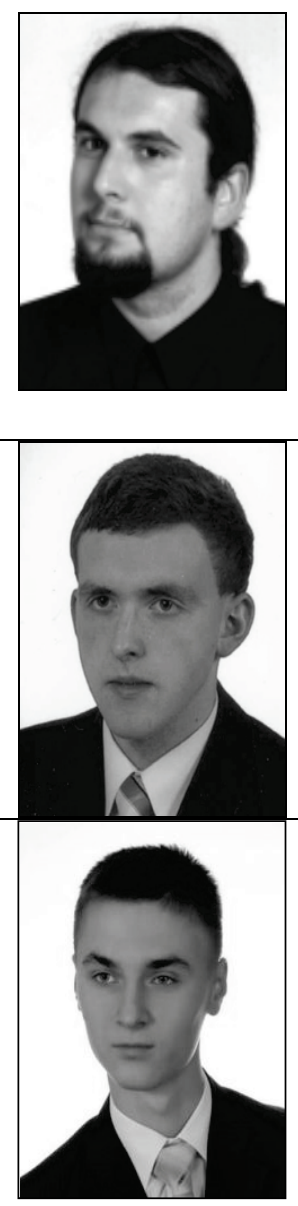

\section{Administrowanie Sieciami Komputerowymi}

\section{Politechnika Lubelska}

Instytut Elektroniki i Technik Informacyjnych

\section{Dwusemestralne studia podyplomowe obejmują moduły kształcenia:}

1 Podstawy administrowania systemem Windows

2 Podstawy administrowania systemem Linux

3 Sieci LAN

4 Sieci IP

5 Routing w sieciach IP

6 Sieci TCP/IP

7 Usługi w sieciach TCP/IP

8 Wykorzystanie Windows w sieciach LAN

9 Wykorzystanie Linux w sieciach LAN

10 Zarządzanie systemami informatycznymi

11 Sieci telekomunikacyjne
12 Serwery usług sieciowych

13 Bezpieczeństwo systemów komputerowych

14 Diagnostyka sieci komputerowych

15 Multimedia strumieniowe

16 Systemy telefonii VoIP

17 Sieci dostępowe

18 Kodowanie informacji multimedialnych

19 Elementy sieci optoelektronicznych

20 Światłowody i kable światłowodowe

21 Podstawy normalizacji

22 Seminarium dyplomowe

Telefon:

(0-81) 5384309 - sekretariat Instytutu Elektroniki i Technik Informacyjnych

(0-81) 5384317 - opiekun ds. organizacyjnych, dr inż. Piotr Kisała

Faks:

(0-81) 5384312

Adres pocztowy:

ul. Nadbystrzycka 38A, 20-618 Lublin

Poczta elektroniczna

ask@politechnika.lublin.pl 